ACTA AGROBOTANICA

Vol. 61 (1): 107-113

2008

\title{
POLLINATION, FERTILIZATION AND FRUIT FORMATION IN EGGPLANT (SOLANUM MELONGENA L.)
}

\author{
Agnieszka Sękara $^{1}$, Monika Bieniasz ${ }^{2}$ \\ ${ }^{1}$ Departament of Vegetable Crops \\ ${ }^{2}$ Department of Pomology and Apiculture \\ Agricultural University in Kraków, 29 Listopada 54, 31-425 Kraków, Poland \\ e-mail: asekara@ogr.ar.krakow.pl
}

Received: 15.09.2007

S u m m a r y

The aim of the investigations was to determine the regularity of pollination and fertilization as dependent on the phenotype of flower in eggplant. The experiment was conducted in 2005 and 2006 at the Agricultural University in Kraków, Poland. The object of the investigations was eggplant (Solanum melongena $\mathrm{L}$.) 'Epic $\mathrm{F}_{1}$ ', grown in the open field. Flower phenotype (long-, medium- or short-styled), fruit setting and the number of seeds per fruit were recorded on experimental plants during the flowering period. The number of pollen tubes in the middle of the style and the number on fertilized ovules in ovaries were evaluated for all types of flowers. The course of pollination was different in particular types of eggplant flowers. Differences concerned only the number of pollen tubes and fertilized ovules of short, medium- and long-styled flowers and the number of seeds in the fruit. There was not observed any incompatibility in the growth on pollen tubes in the styles of all types of eggplant flowers. Stereomicroscopy observations of cross sections of the ovaries do not show differences in the formation and position of the ovules on the placenta. Short-styled flowers were characterized by significantly lower pollination and fruit set efficiency and they produced fruits with a significantly lower number of seeds. The low number of pollen tubes, fertilized ovules and seeds can be a straight consequence of the morphology of short-styled flowers: small-sized stigmas and spatial separation of anther pores and stigmas, which makes pollination difficult.

Key words: Solanum melongena, heterostyly, pollination efficiency, fertilization efficiency

\section{INTRODUCTION}

Flowering and fruit set are two most important factors determining the yield of cultivated eggplants. Genotype and environmental factors influence the course of flowering and the flower morphology, especially the style length which determines the effectiveness of fruit setting. Eggplant is a self-pollinated plant - pollen does not need a pollinator to transfer it in the field. It is a partly self-incompatible species and needs cross-fertilization for greater fruit set (A m o a k o and $\mathrm{Ye} \mathrm{bo} \mathrm{a} \mathrm{h} \mathrm{-}$ $\mathrm{G}$ y a n, 1991). In hot humid climate, cross-pollination may occur up to $20 \%$, mainly due to heterostyly, even though it is treated as a self-pollinated crop ( $\mathrm{S}$ w a r u p, 1995). Quagliotti (1979) estimated the amount of cross pollination in eggplant at between 0 and $46 \%$, but cross pollination at distances of $50 \mathrm{~m}$ or more was nonexistent. The flower remains open for 2-5 days without closing at night. Anthesis and pollen release occur in the morning, but these phenomena are influenced by the daylight, temperature, and humidity. Pollen viability is retained for $8-10$ days at a temperature of $20-22^{\circ} \mathrm{C}$ with a relative humidity of $50-55 \%(\mathrm{C} \mathrm{h}$ e $\mathrm{n}, 2001)$. In eggplant, fertilization is completed within 3 days after pollination and gene expression 3 days after anthesis is induced by stimuli of both pollen tube elongation and fertilization. Ovaries of unpollinated flowers began to senesce 3 days after anthesis, although half of them had the potential to set fruit ( $\mathrm{N}$ a g a s a w a et al. 2001).

The variation in style length and its position towards stamens was widely described in eggplant. Longstyled flowers (the stigma is above the stamen or on the same level as the stamen) are always more appreciable in the number than short-styled flowers (the stigma is below the stamen). Sometimes flowers with the stigma on the same level as the stamen are defined as mediumstyled ones. Krishnamurthi and Subraman i a m (1954) described four types of flowers: 1) long styled with large ovary, 2) medium styled with medium sized ovary, 3) pseudoshort-styled with rudimentary ovary, and 4) true-short-styled with very rudimentary ovary. Pseudo- and short-styled flowers fail to set fruits, whereas long- and medium-styled flowers produce fruits. Fruit set rates are higher for long-styled flowers compared with short-styled flowers, so short-styled ones 
are not totally sterile ( $\mathrm{C}$ h e $\mathrm{n}, 2001)$. In long-styled flowers, the stigma may project beyond the anthers, what favours cross-pollination. N ot hmann et al. (1983) stressed that stylar heteromorphism affected fruit set more than did the position of the flower in the cluster. According to Pas s a m and B olmat is (1997). the proximity of the stigma to the anther pores at anthesis influences fruit set, fruit size and seed content, but not seed quality of eggplant. Fruit weight and seed formation were maximal in flowers with the stigmata at maturity situated close to the anther pores. There are some investigations designed to determine the influence of agronomical and environmental factors on the occurrence of different types of flowers in eggplant. P a s s a m and Bolmatis (1997) showed that the style length in eggplant is a varietal characteristic. B o b a d i and van D a m m e (2003) stated that nitrogen failed to influence style length and type of flowers of eggplant. According to K o w a ls k a (2003), eggplant formed the highest number of flowers with a long pistil and much less flowers with medium and short pistils regardless of the pollination method (self pollination, using bumble bees) and flower hormonization.

The production of short-styled flowers with a small and highly reduced gynoecium, often infertile or with small possibilities of setting fruits, seems to be the first step to functional andromonoecy - the production of staminate and hermaphroditic flowers. Andromonoecy is widespread in the genus Solanum (Dulberger et al. 1981; Solomon, 1986; Diggle and Mille r, 2004). The aim of the present investigations was to discuss the reasons and benefits of eggplant stylar heteromorphism and to determine the regularity of pollination and fertilization as dependent on the type of flower.

\section{MATERIALS AND METHODS}

The experiment was conducted in 2005 and 2006 at the Agricultural University in Kraków, Poland. The object of investigations was eggplant (Solanum melongena L.) 'Epic $\mathrm{F}_{1}$ ', grown in the open field, in the Experimental Station in Mydlniki, near Kraków, South Poland. Seeds were sown on 4th March 1995 and 3rd March 2006 in seed-boxes filled with peat substrate and placed in a controlled environment: temperature $27 \pm$ $1^{\circ} \mathrm{C}$ and $\mathrm{RH} 80 \%$. After emergences, temperature was maintained at $26 \pm 2{ }^{\circ} \mathrm{C}$ (day) and $21 \pm 1^{\circ} \mathrm{C}$ (night), $\mathrm{RH}$ at $80 \%$. When the first true leaf was expanding, uniform seedlings were pricked out into plastic containers $\varnothing 8$ $\mathrm{cm}$, filled with peat based substrate. Uniform transplants with 5-6 leaves were finally transplanted into open field at the beginning of May, 70 and 62 days after sowing (in 2005 and 2006, respectively), in a spacing of 0.75 $\times 0.60 \mathrm{~m}$. Eggplant was grown in standard agronomic conditions. The observations were conducted on 20 plants during the whole flowering period. Single flowers were numbered according to the order of appearance on each plant. Flower phenotype (long-, medium- or shortstyled), fruit setting and the number of seeds per fruit were recorded for all plants. Results were evaluated by ANOVA, Tukey's test, at $\mathrm{p}=0.05$. At full flowering (17.07.2005 and 26.07.2006), 60 flowers of each type (long-, medium- and short-styled) were collected. Only pollinated flowers were taken into consideration. In the first part of the investigations, 30 styles of each above mentioned type were isolated and fixed immediately in FAA (formalin-acetic-alcohol), according to Martin's method (Martin, 1959). Germination of pollen on stigmas, growth of pollen tubes and fertilization of ovules were examined under fluorescence microscopy.

Table 1

The effectiveness of fertilization and fruit setting as dependent on the type of flower in eggplant.

\begin{tabular}{|c|c|c|c|c|c|c|c|c|}
\hline Type of flower & $\begin{array}{l}\text { Long- } \\
\text { styled }\end{array}$ & $\begin{array}{l}\text { Medium- } \\
\text { styled }\end{array}$ & $\begin{array}{l}\text { Short- } \\
\text { styled }\end{array}$ & $\operatorname{LSD}_{0.05}$ & $\begin{array}{l}\text { Long- } \\
\text { styled }\end{array}$ & $\begin{array}{l}\text { Medium- } \\
\text { styled }\end{array}$ & $\begin{array}{l}\text { Short- } \\
\text { styled }\end{array}$ & $\mathrm{LSD}_{0.05}$ \\
\hline Year & \multicolumn{4}{|c|}{2005} & \multicolumn{4}{|c|}{2006} \\
\hline $\begin{array}{l}\text { Pollination } \\
\text { efficiency }(\%)\end{array}$ & 44.2 & 39.9 & 17.3 & 7.86 & 38.8 & 50.8 & 30.2 & 8.84 \\
\hline $\begin{array}{l}\text { Fruit set } \\
\text { efficiency }(\%)\end{array}$ & 58.7 & 54.6 & 8.6 & 6.56 & 61.2 & 51.8 & 36.8 & 27.47 \\
\hline $\begin{array}{l}\text { Number of seeds } \\
\text { per fruit }\end{array}$ & 372.5 & 358.5 & 141.0 & 70.52 & 376.5 & 376.3 & 217.8 & 44.15 \\
\hline
\end{tabular}


The number of pollen tubes in the half of the style and the number of fertilized ovules were evaluated. In the second part of observations, the cross sections of 30 sty-

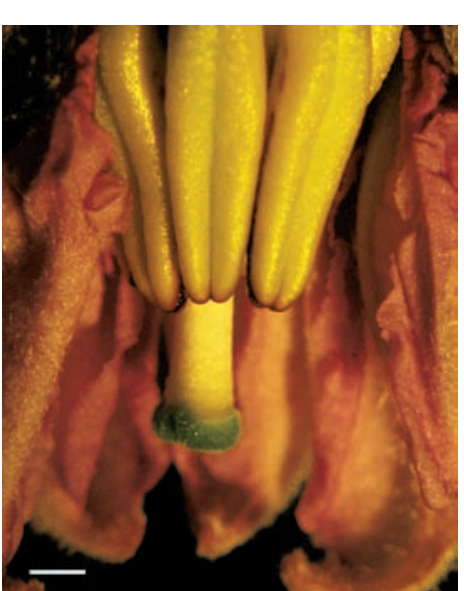

I.

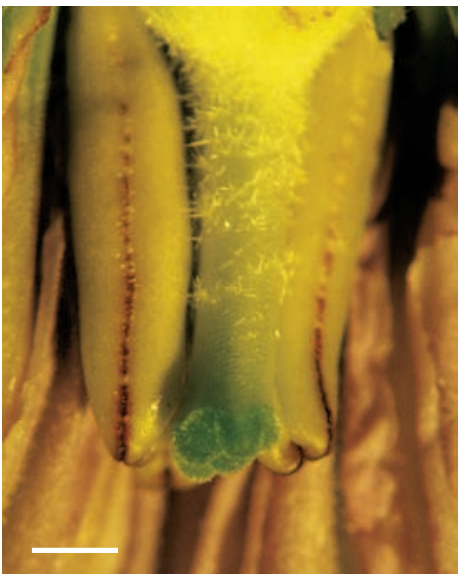

II. les of each abovementioned type were observed under stereomicroscopy to evaluate the regularity of ovule formation.

Fig. 1. Stylar heteromorphism in eggplant: I. Long-styled flower, scale bar $=1 \mathrm{~mm}$, II. Medium-styled flower, scale bar $=1 \mathrm{~mm}$, III. Short-styled flower, scale bar $=1 \mathrm{~mm}$.

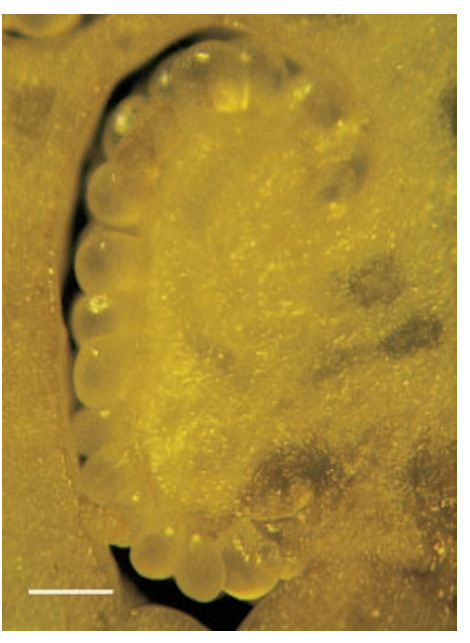

I.

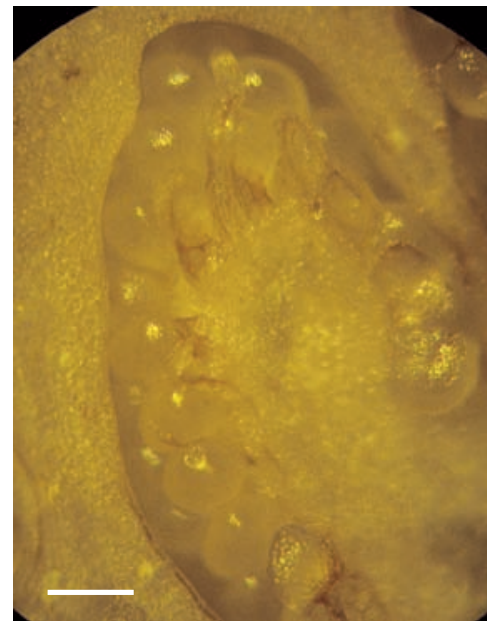

II.

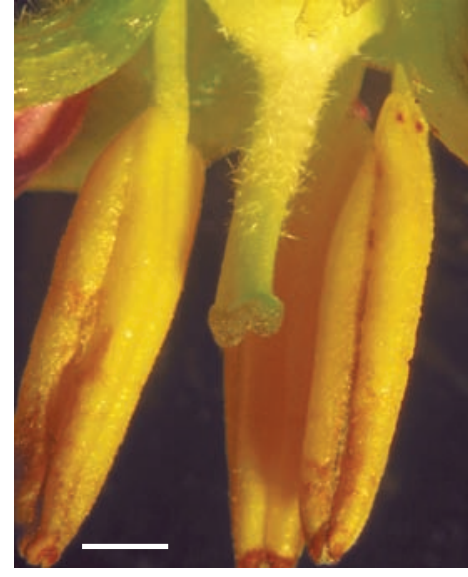

III.

Fig. 2. Position of the ovules on the placenta (cross sections of the fragment of eggplant ovary): I. Long-styled flower, scale bar $=100 \mu \mathrm{m}$, II. Medium-styled flower, scale bar $=100 \mu \mathrm{m}$, III. Short-styled flower, scale bar $=100 \mu \mathrm{m}$.

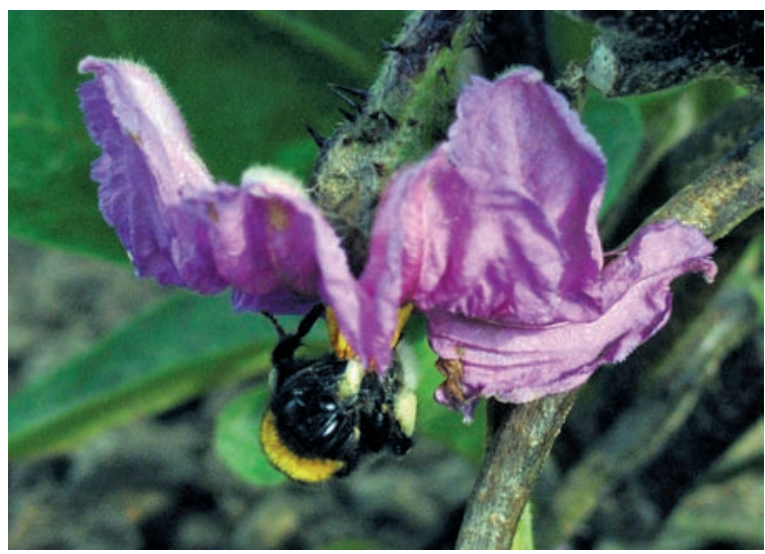

Fig. 3. Bumble bees on eggplant flowers.

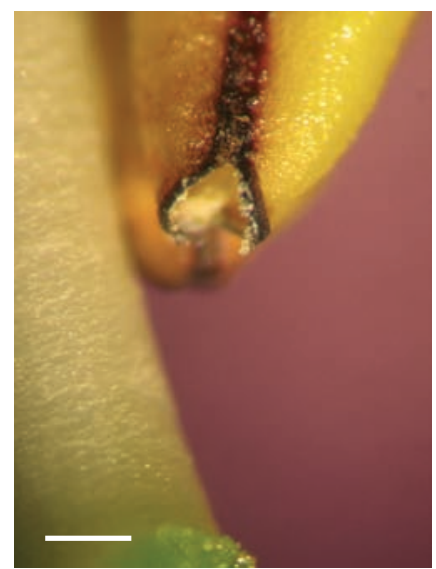

Fig. 4. Terminal pores of the stamens in long-styled flower of eggplant, scale bar $=0.5 \mathrm{~mm}$. 


\section{RESULTS}

Stylar heteromorphism was a distinct phenomenon of eggplant 'Epic $F_{1}$ ' in the conditions of the present experiment. The plants produced three types of flowers: long-styled, medium-styled and short-styled (Figs 1, I-III). Stereomicroscopy observations of cross sections of the ovaries do not show differences in the formation and position of the ovules on the placenta (Figs 2, I-III). Bumble bees (Bombus terrestris) were widely observed on turned down flowers (Fig. 3). There were no morphological differences in the forming of anthers among the long-, medium- and short-styled flowers. The stamens formed a cone like a tube around the style and dehisced at the terminal pores (Fig. 4). Stamen pores of the me- dium-styled flowers were localized closest to the stigma of the style.

Pollination efficiency of the long- and mediumstyled flowers was the greatest and was contained in the range of 38.8-50.8\% (Tab. 1). Pollination efficiency of the short-styled flowers was significantly lower (17.3 and $30.2 \%$, in subsequent years of the experiment). In 2005, fruit set efficiency of the long- and medium-styled flowers was much higher as compared to the short-styled ones. In 2006, significant differences in fruit setting between the investigated types of flowers were not observed. Fruits set from the long- and medium-styled flowers contained a comparable number of seeds (371.0 seeds per fruit, on average). Fruits set from the short-styled flowers contained about two times less of seeds (179.4 seeds per fruit).

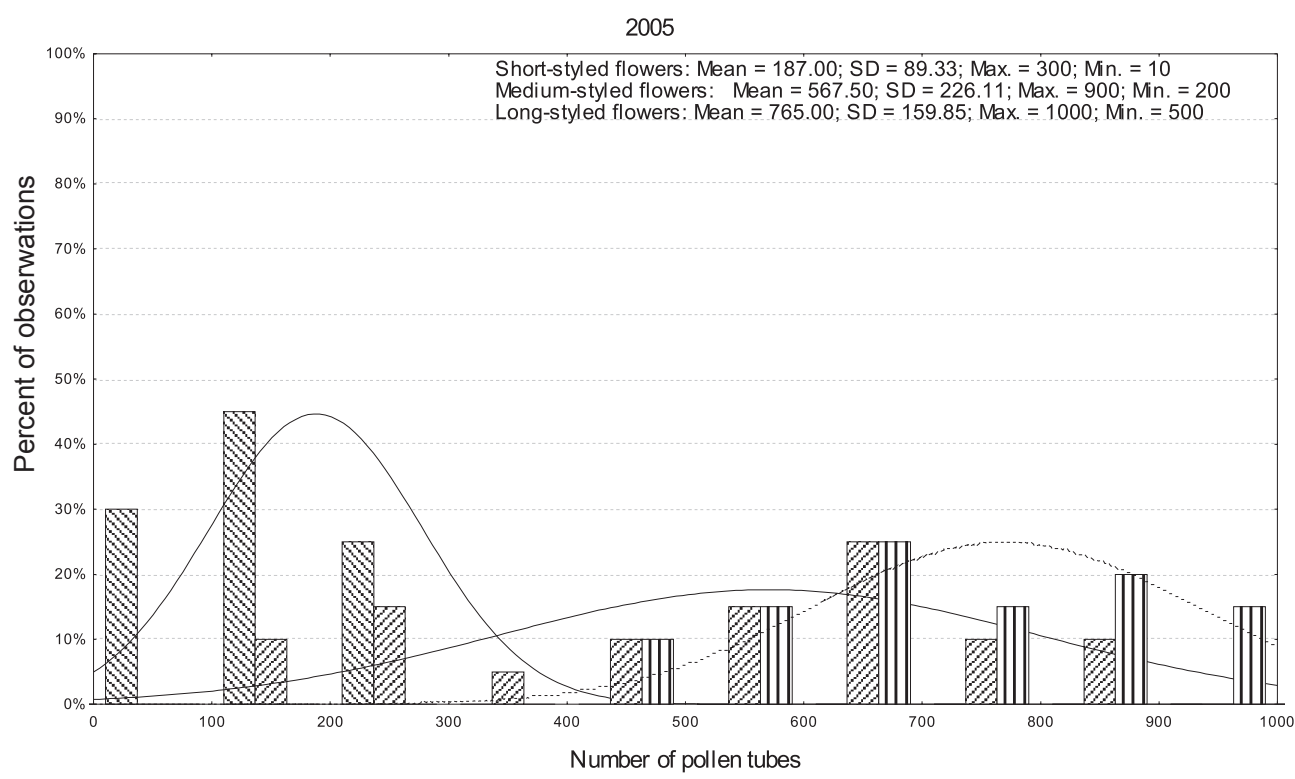

Short-styled flowers 68) Medium-styled flowers Will Long-styled flowers

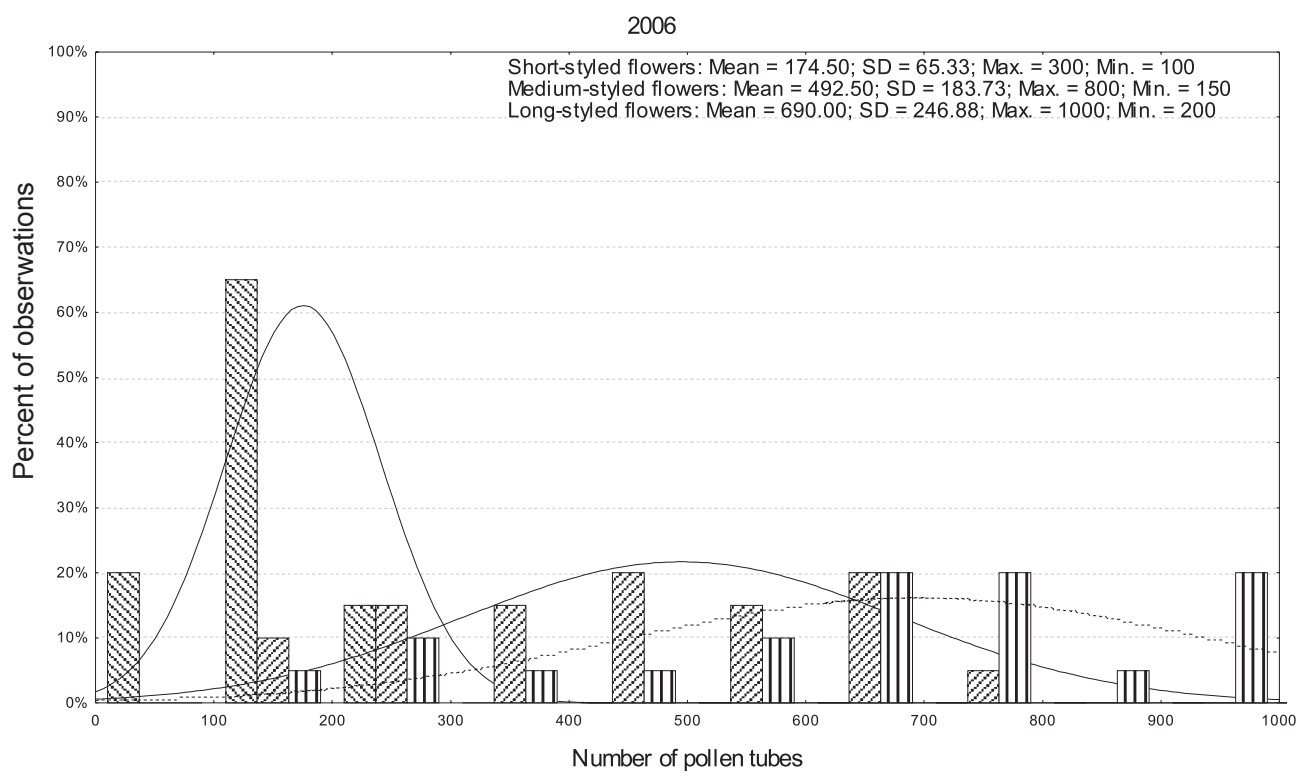

Short-styled flowers $\ll$ Medium-styled flowers 讯 Long-styled flowers

Fig. 5. Number of pollen tubes in the styles of different types of eggplant flowers. 

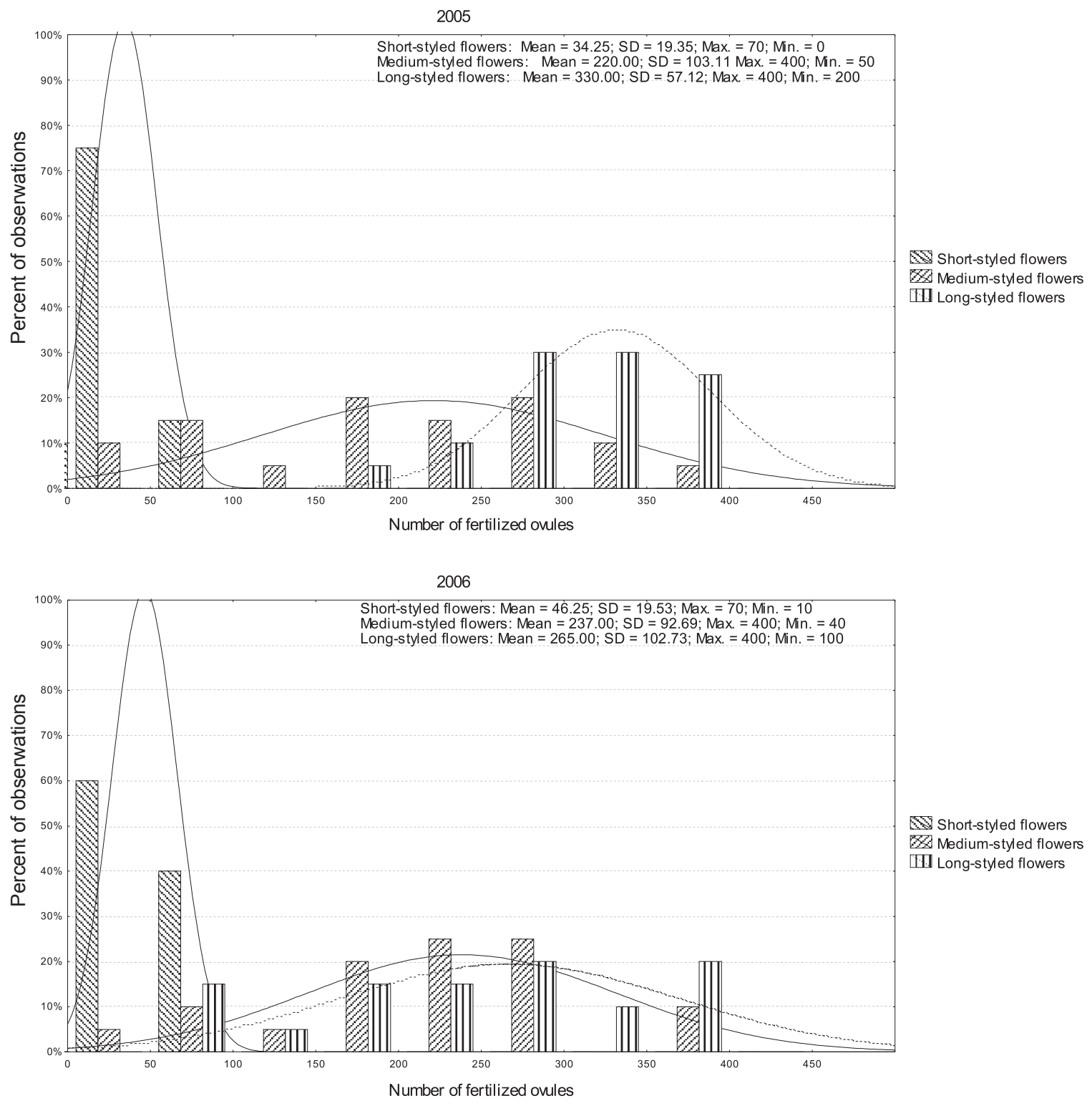

Fig. 6. Number of fertilized ovules in the pistils of different types of eggplant flowers.

There was not observed any incompatibility in the growth on pollen tubes in the styles of all types of eggplant flowers. Pollen tubes grew into the style with seven ducts. Long-, medium-, and short-styled flowers were differentiated only in relation to the number of pollen tubes observed in the styles. There was found 10-300 pollen tubes in the middle of the style in the short-styled flowers, 150-900 in medium-styled, and 200-1000 in long-styled ones (Fig. 5). The ovaries of the short-styled flowers contained 0-70 fertilized ovules. Many more fertilized ovules were found in the remaining types of flowers: 40-400 in medium-styled and 100-400 in longstyled ones (Fig. 6).

\section{DISCUSSION}

Analysis of the recent reports on the flowering biology of cultivated eggplants brings the question if the eggplant heterostyle is a transitional stage between hermaphroditism and andromonoecy and what the benefits of eggplant heterostyly are. Andromonoecy has been mentioned as a frequent phenomenon for cultivated eggplants (Hawkes et al. 1979; Anders on and Sym o n, 1989). Differences between medium- and longstyled flowers concerned only the pistil morphology; the pollination and fruit set efficiency as well as the number of seeds per fruit of the mentioned types of flowers were 
similar. In the conditions of the present experiment, the short-styled hermaphroditic flowers of eggplant were not functionally pistillae. The short-styled flowers were fertile and able to set fruits but fruit set rates were greater for the medium- and long-styled flowers, as it was reported by C h e n (2001) and K ow a ls k a (2003). The high frequency of short-styled flowers was coincident with the peak flowering period of the investigated eggplant cultivar (data not shown). It may be an adaptation in preventing excessive fruit set. P a s s a m et al. (2000) found that the transitory reduction in style length, due to the presence of the fruit in the stage of growth, may lead to a temporary reduction in fertility of eggplant. Authors suggested that fruit load and development affect flower mass and style length of eggplant, whereas auxins influence the number of flowers. The flowers of plants that did not set fruits showed only minor fluctuations in flower and pistil mass and style and anther length.

S a m b and am (1964) stated that $30-40 \%$ of the eggplant fruit set is attributed to pollination by contact, gravity and wind, the rest is dependent on insects. Chen (2001) stated that the cone-like formation of eggplant anthers favors self-pollination; but since the stigma ultimately projects beyond the anthers, there is ample opportunity for cross-pollination. Such kind of the androecium indicates the adaptation to the buzz-pollination mechanism. In buzz-pollination, insects grasp the anther cone and transmit vibrations through their bodies to the anthers, thus producing pollen expulsion from the anther apices (B u c h m a n , 1983). This feature restricts pollination to a group of insects which are able to vibrate the anthers, i.e. bumble bees (B e z e r r a and $\mathrm{Machado}, 2003)$. Bumble bees were common on the flowers of eggplant in the conditions of the present experiment (open field plantation). The buzz-pollination mechanism enabled bumble bees to pollinate all types of eggplant flowers, whereas self-pollination was prevented in short-styled flowers because of the spatial separation of terminal pores and the stigma in turned down flowers (Fig. 1, III; Fig. 4). It was possible that the short-styled flowers were maintained by the plant to attract insects with pollen as a reward. The short-styled flowers were fertile, despite of the reduced size of the pistil, but pollination was hampered. If it had occurred (mainly by insects), flowers set fruits. Co n n o $11 \mathrm{y}$ and Anderson (2004) investigated the role of the androecium in male and hermaphroditc flowers of andromonoecious Solanum carolinense. The anthers in these two types of flowers had the same size and they bear the same quantity of pollen, but their differed in their role in pollination. Male organs of hermaphroditic flowers were the source of pollinator reward (pollen), at least as near distance attractive elements, and as landing platforms. The stamens of the male flowers functioned primarily as possible near-distance attractors and as the source of pollen for reproduction. In Solanum palinacanthum, the yellow anthers were shown to be more important attractants than was the corolla ( $\mathrm{Cole} \mathrm{man}$ and Coleman, 1982).

The incompatibility in the growth on pollen tubes in the short styles was not observed, so a smaller number of pollen tubes, noticed in short-styled flowers, may have a morphological substratum: the above mentioned pollination difficulties and small sized stigmas of shortstyled flowers which absorb less pollen. A low number of pollen tubes, fertilized ovules and seeds can be a straight consequence of short-styled pistil morphology and a way of pollination. R y l s k i et al. (1984) showed that pistils with a style length of less than $0.5 \mathrm{~cm}$ tend to be smaller than medium- or long-styled ones and carry a relatively small stigma with undeveloped papillae and a low sugar content that precludes pollen germination and thus results in pollen drop. $\mathrm{P}$ a s s a $\mathrm{m}$ and $\mathrm{B} \mathrm{ol}-$ $\mathrm{m}$ at is (1997) found that flowers of style length $<0.5$ $\mathrm{cm}$ had significantly smaller ovaries and failed to set fruits. In flowers with style length greater than $0.51 \mathrm{~cm}$, the ovary size was quite similar.

\section{ACKNOWLEDGEMENTS}

The study was supported by the project grant of the Ministry of Science and High Education No. 2P06R 06429.

\section{REFERENCES}

Amoako J., Yeboah-Gyan K., 1991. Insect pollination of three Solanaceous vegetable crops in Ghana with special reference to the role of African honey bee (Apis mellifera Adansonii) for fruit set. Acta Hort. 288: 255-259.

Anderson G. J., Symon D. E., 1989. Functional dioecy and andromonoecy in Solanum. Evolution, 43 (1): 204-219.

Bobadi S., van Damme P., 2003. Effect of nitrogen application on flowering and yield of eggplant. Commun. Agric. Appl. Biol. Sci. 68 (1): 5-13.

Bezerra E. L., Machado I. C., 2003. Biologia floral e sistema de polinização de Solanum stramonifolium Jacq. (Solanaceae) em remanescente de Mata Atlântica, Pernambuco. Acta Bot. Bras. 17 (2): 247-257.

Buchmann S. L., 1983. Buzz pollination in Angiosperms. [In:] Handbook of experimental pollination biology. C.E. Jones, R.J. Little (eds), Van Nostrand \& Reinhold, New York.

Chen N. C., 2001. Eggplant seed production. AVRDC, International Cooperators' Guide. Asian Vegetable Research and Development Center, Shanhua, Taiwan.

Coleman J. R., Coleman M. A., 1982. Reproductive biology of an andromonoecious Solanum (S. palinacanthum Dunal). Biotropica, 14 (1): 69-75.

Connolly B. A., Anderson G. J., 2004. Functional significance of the androecium in staminate and hermaphroditic 
flowers of Solanum carolinense (Solanaceae). Plant Syst. Evol. 240 (1-4): 235-243.

Diggle P. K., Miller J. S., 2004. Architectural effect mimic floral sexual dimorphism in Solanum (Solanaceae). Am. J. Bot. 9 (12): 2030-2040.

Dulberger R., Levy A., Palevitch D., 1981. Andromonoecy in Solanum marginatum. Bot. Gaz. 142 (2): 259-266.

Hawkes J. G., Lester R. N., Skelding A. D., 1979. Biology and taxonomy of the Solanaceae. Academic Press, London.

Kowalska G., 2003. The influence of heterostyly, pollination method and hormonization on eggplant's (Solanum melongena L.) flowering and fruiting. Acta Agrobot. 56 $(1 / 2): 61-76$.

Krishnamurthi S., Subramanian D., 1954. Some investigations on the types of flowers in bringal (Solanum melongena) based on style length, and their fruit set under natural conditions and in response to 2,4-chloropehono$\mathrm{xy}$-acetic acid as a plant growth-regulator. Indian J. Hort. 11 (1): 63-65.

Martin F. W., 1959. Staining and observing pollen tubes in the style by means of fluorescence. Stain Technol. 34: 125128.

Nagasawa M., Sugijama A., Mori H., Shiratake K., Yamaki S., 2001. Analysis of genes preferentially expressed in early stage of pollinated and parthenocarpic fruit in eggplant. J. Plant Physiol. 158: 235-240.

Nothmann J., Rylski I., Spigelman M., 1983. Interactions between floral morphology, position in cluster and 2,4-D treatments in three eggplant cultivars. Sci. Hort. 20 (1): $35-44$.

Passam H.C., Baltas C., Boyiatzoglou A., Khah E. M., 2000. Flower morphology and number of aubergine ( $\mathrm{So}$ lanum melongena $\mathrm{L}$.) in relation to fruit load and auxin application. Sci. Hort. 1595: 1-8.

Passam H. C., Bolamtis A., 1997. The influence of style length on the fruit set, fruit size and seed content of aubergines cultivated under high ambient temperature. Trop. Sci. 37: 221-227.

Quagliotti L., 1979: Floral biology of Capsicum and Solanum melongena. [In:] The biology and taxonomy of the Solanaceae. J. G. Hawkes, R. N. Lester, A. D. Skelding (eds), London, Academic Press.
Rylski I., Nothmann J., Arcan L. 1984. Differential fertility in short styled eggplant flowers. Sci. Hort. 22 (1-2): 3946.

Samband a m C. N., 1964. Natural cross-pollination in eggplant (Solanum melongena). Econ. Bot. 18 (2): 128-131.

Solomon B. P., 1986. Sexual allocation and andromonoecy: resource investment in male and hermaphrodite flowers of Solanum carolinense (Solanaceae). Am. J. Bot. 73 (8): 1215-1221.

Swarup V., 1995. Genetic resources and breeding of aubergine (Solanum melongena L.). Acta Hort. 412: 71-79.

\section{Zapylenie, zapłodnienie i wiązanie owoców u oberżyny (Solanum melongena L.)}

\section{Streszczenie}

Celem badań było określenie prawidłowości zapylenia i zapłodnienia u oberżyny w zależności od budowy morfologicznej kwiatu. Badania prowadzono w latach 2005 i 2006 w Akademii Rolniczej w Krakowie. Obiektem badań była odmiana Epic $\mathrm{F}_{1}$, uprawiana $\mathrm{w}$ polu. W okresie kwitnienia analizowano występowanie poszczególnych typów słupków (długo-, średnio- i krótko-szyjkowych). Określono liczbę łagiewek pyłkowych w przerastających szyjkę analizowanych typach słupków i liczbę zapłodnionych zalążków. Stwierdzono różnice $\mathrm{w}$ przebiegu zapylenia i zapłodnienia pomiędzy poszczególnymi typami słupków, dotyczące liczby łagiewek pyłkowych i zapłodnionych zalążków oraz liczby nasion w owocach. Nie stwierdzono niezgodności w przeroście łagiewek pyłkowych w szyjce słupka. Obserwacje stereomikroskopowe nie wykazały różnic w uformowaniu i ułożeniu zalążków na łożyskach poszczególnych typów słupków. Słupki krótko-szyjkowe charakteryzowała istotnie mniejsza efektywność zapylenia i zapłodnienia, a zawiązane $\mathrm{z}$ nich owoce zawierały najmniej nasion. Mała liczba łagiewek pyłkowych i zapłodnionych zalążków w kwiatach krótko-szyjkowych może być wynikiem małych rozmiarów znamienia i jego oddalenia od pylników, utrudniającego zapylenie. 
